\title{
Recommendations for the Management of Constipation in Cancer Patients
}

\author{
Justin Arnall ${ }^{1 *}$ and Issam Hamadeh ${ }^{2}$ \\ ${ }^{1}$ Oncology Clinical Team Lead, Levine Cancer Institute, USA \\ ${ }^{2}$ Clinical Pharmacogenetics Pharmacist, Levine Cancer Institute, USA
}

Submission: September 08, 2018; Published: October 22, 2018

*Corresponding author: Justin Arnall, Oncology Clinical Team Lead, Carolina HealthCare, System, Levine Cancer Institute, 1021 Morehead Medical Drive, Charlotte, North Carolina 28204, Tel: 336-682-8732; Email: jarnall87@gmail.com

\begin{abstract}
Constipation is a common condition that is often overlooked among cancer patients particularly those with advanced disease. It is often associated with distressing or debilitating symptoms that adversely impact the quality of life of these patients. Hence, it is imperative that practicing clinicians are cognizant of the various etiologies of constipation especially those that are secondary to both cancer therapies and supportive care. Since discontinuation of the offending drug(s) may not be a viable option in the hematology/oncology setting, patient counseling and initiation of preventative measures which include scheduled bowel regimens for therapies known to cause constipation are central to optimal management. As constipation goes unresolved or becomes more severe laxative therapy should be optimized to achieve resolution of symptoms. In severe and refractory cases of constipation consulting a gastrointestinal specialist may be prudent. Herein, we highlight the most common laxative therapies that may be considered in adult cancer patients experiencing initial and refractory constipation as well as provide practical considerations and a management algorithm that can be easily applied or implemented in clinical practice.
\end{abstract}

Keywords: Cancer; Gastrointestinal; Patients; Management

\section{Introduction}

Constipation is the most common gastrointestinal disorder accounting for over 2 million clinic visits annually. The prevalence of constipation ranges from $2-27 \%$ among the US population $[1,2]$. This condition causes very distressing symptoms that may compound the symptoms of cancer and its treatment; thereby affecting the quality of life of these patients. If left untreated, constipation may cause abdominal pain, distention, urinary retention, nausea, vomiting, anorexia, development of hemorrhoids, anal fissures, perianal abscesses, and intestinal obstruction which could be life-threatening.

The term constipation is associated with infrequent bowel movements, and often equated with straining, hard stool or abdominal discomfort. 3 The ROME III criteria were developed to standardize the definition of constipation and provide a comprehensive approach to its diagnosis. Based on these criteria, the diagnosis of constipation requires the presence of at least two of the following symptoms for the past three months or 12 weeks (with symptom onset at least 6 months prior to diagnosis) [3].

a) Straining during at least $25 \%$ of defecations

b) Lumpy or hard stools in at least $25 \%$ of defecations c) Sensation of incomplete evacuation for at least $25 \%$ of defecations

d) Sensation of anorectal obstruction for at least $25 \%$ of defecations

e) Manual maneuvers to facilitate at least $25 \%$ of defecations

f) Fewer than three defecations per week

g) Loose stools are rarely present without the use of laxatives and there are insufficient criteria for diagnosis of irritable bowel syndrome

The diagnosis of constipation includes conducting a careful physical exam (abdominal and rectal examination, signs of anemia, weight loss, and liver enlargement) and obtaining a thorough patient history (duration, stool frequency, straining, and medication history and comorbidities) for the purposes of ruling out secondary causes of constipation [4]. Other studies or further work up including colonoscopy is generally not warranted unless patients present with alarming symptoms [4].

The etiology of constipation is multifactorial, though can be simplistically classified into primary (idiopathic) or secondary constipation $[5,6]$. Primary constipation arises from colonic or 
anorectal dysfunction (due to intrinsic causes), and secondary constipation is attributed to an underlying disease state or use of certain medications [6] (Table 1) lists the major drug classes known to contribute to the development of constipation. If a medication or medical condition is the cause of constipation, eliminating the offending medication or treating the underlying medical condition may lead to its resolution. Since drug Table 1: Drug classes associated with constipation $[6,7,10,11]$.

\begin{tabular}{|c|}
\hline Drug class \\
\hline Cancer Therapies \\
\hline Alkylating agents \\
\hline Topoisomerase II inhibitors \\
\hline Proteasome inhibitors \\
\hline Immunomodulatory agents \\
\hline Aromatase inhibitors \\
\hline Antiandrogens \\
\hline Common Supportive Therapies \\
\hline Opioid analgesics \\
\hline Antidepressants (tricyclics) \\
\hline 5-HT3 receptor antagonists \\
\hline Antispasmodics \\
\hline Antipsychotics \\
\hline Antihistamines \\
\hline Antiepileptics \\
\hline Supplements \\
\hline Antidiarrheal agents \\
\hline Antiresorptive agents \\
\hline Bile acid sequestrants \\
\hline
\end{tabular}

When no secondary cause of constipation is identified, empiric treatment should be initiated. Non-pharmacologic methods (bowel training, increasing fiber intake thru diet or bulk agents, fluid intake, and exercise) should be considered first to improve bowel regularity prior to proceeding to the use

Table 2: Drug classes associated with constipation $[6,7,10,11]$.

\begin{tabular}{|c|c|c|c|}
\hline Medication & Onset of Action & Onset of Action & Comments \\
\hline $\begin{array}{l}\text { Docusate sodium Docusate } \\
\text { calcium }\end{array}$ & $\begin{array}{l}50-300 \mathrm{mg} \text { daily orally in } 1-2 \text { doses } 240 \mathrm{mg} \\
\text { daily orally }\end{array}$ & $12-72$ hours (oral) & $\begin{array}{l}\text { Recommend adequate } \\
\text { hydration }\end{array}$ \\
\hline Bisacodyl & $5-15 \mathrm{mg}$ orally daily $10 \mathrm{mg}$ per rectum daily* & 6-12 hours (oral) & $\begin{array}{l}\text { Avoid within an hour of } \\
\text { antacids or milk }\end{array}$ \\
\hline Senna & $\begin{array}{l}8.6 \text { mg sennosides orally } 1 \text { twice to } 2 \text { four } \\
\text { times daily times daily } 5-15 \text { ml daily oral } \\
\text { solution }\end{array}$ & $6-24$ hours & $\begin{array}{l}\text { Maximum at } 8 \text { tablets } \\
\text { ( } 30 \mathrm{ml} \text { of liquid) daily }\end{array}$ \\
\hline $\begin{array}{l}\text { Magnesium hydroxide } \\
\text { Magnesium citrate }\end{array}$ & $\begin{array}{l}\text { Suspension }(400 \mathrm{mg} / 5 \mathrm{ml}) \text { PO } 30-60 \mathrm{ml} \text { daily } \\
\text { Solution }(1.75 \mathrm{~g} / 30 \mathrm{ml}) \text { PO } 5-10 \text { floz daily }\end{array}$ & 30 minutes to 6 hours & $\begin{array}{l}\text { Consider chilling } \\
\text { magnesium citrate prior } \\
\text { to administration }\end{array}$ \\
\hline $\begin{array}{l}\text { PEG without electrolytes } \\
\text { PEG with electrolytes }\end{array}$ & $\begin{array}{c}17 \mathrm{~g} \text { orally } 1-2 \text { times daily in } 8 \mathrm{fl} \text { oz } 200- \\
500 \mathrm{ml} \text { orally daily }\end{array}$ & 24 to 96 hours 1 hour & $\begin{array}{l}\text { PEG with electrolyte: } \\
\text { dosage for bowel } \\
\text { cleansing } 240 \text { ml every } \\
10 \text { min until diarrhea } \\
\text { fluid is clear or until } 4-5 \\
\text { L consumed }\end{array}$ \\
\hline
\end{tabular}

discontinuation may not be a viable option in the hematology/ oncology setting, patient counseling and initiation of preventative measures are central to optimal management. For example, opiates are commonly used to manage cancer-associated pain, and almost always cause some degree of constipation. This complication can be mitigated if a proper bowel regimen is considered when prescribing chronic opioid therapy.

\begin{tabular}{|c|}
\hline Examples \\
\hline Cisplatin, carboplatin, temozolamide \\
\hline Vincristine, vinorelbine, vinblastine \\
\hline Liposomal doxorubicin \\
\hline Bortezomib, carfilzomib \\
\hline Lenalidomide, pomalidomide, thalidomide \\
\hline Letrozole, anastrazole \\
\hline Bicalutamide \\
\hline Morphine, oxycodone, fentanyl, hydrocodone \\
\hline Amitriptyline, nortriptyline \\
\hline Ondansetron, granisetron \\
\hline Mebeverine, dicyclomine \\
\hline Chlorpromazine, clozapine, haloperidol \\
\hline Diphenhydramine, promethazine \\
\hline Carbamazepine, phenytoin \\
\hline Calcium, iron salts \\
\hline Loperamide \\
\hline Zoledronic acid, denosumab \\
\hline Cholestyramine \\
\hline
\end{tabular}

of laxatives [6] Because of the progressive nature of the disease, it may not be feasible to optimize these strategies in cancer patients, and subsequently pharmacologic interventions may be required to prevent or treat constipation (Table 2). 


\begin{tabular}{|c|c|c|c|}
\hline Lactulose & $\begin{array}{l}15-45 \mathrm{ml} \text { solution orally } 1-4 \text { times daily } 300 \\
\text { ml solution in } 700 \mathrm{ml} \text { of water or normal } \\
\text { saline retained for } 30-60 \text { minutes* }\end{array}$ & $\begin{array}{l}\text { (for constipation): } 24-48 \text { hours } \\
\text { to normal bowel movement; } 2-4 \\
\text { administrations with aggressive dosing } \\
\text { Enema may be repeated in } 4-6 \text { hours }\end{array}$ & $\begin{array}{l}\text { Hourly or every other } \\
\text { hour doses of } 20-45 \mathrm{ml} \\
\text { may be used to induce } \\
\text { rapid laxation ( } 20 \\
\text { ml every } 2 \text { hours is a } \\
\text { common consideration) } \\
\text { If enema is evacuated } \\
\text { too quickly consider } \\
\text { redosing immediately }\end{array}$ \\
\hline Sorbitol & $\begin{array}{c}30 \mathrm{ml} \text { oral solution daily } 20 \mathrm{ml} 25-30 \% \\
\text { solution per rectum* }\end{array}$ & $\sim 1$ hour & $\begin{array}{l}\text { Hourly doses of } 30 \mathrm{ml} \\
\text { may be used to induce } \\
\text { rapid laxation }\end{array}$ \\
\hline Methylnaltrexone bromide & $\begin{array}{c}\text { Weight-based subcutaneous injection: }<38 \\
\mathrm{~kg}, 0.15 \mathrm{mg} / \mathrm{kg} 38-61 \mathrm{Kg}, 8 \mathrm{mg} 62-114 \mathrm{~kg} \\
12 \mathrm{mg}>114 \mathrm{~kg}, 0.15 \mathrm{mg} / \mathrm{kg} 450 \mathrm{mg} \text { once } \\
\text { daily orally }\end{array}$ & $\begin{array}{c}\text { (In responding patients) } 30 \text { to } 60 \\
\text { minutes } 1 \text { to } 3 \text { days }\end{array}$ & $\begin{array}{c}\text { Contraindicated in } \\
\text { known or suspected } \\
\text { gastrointestinal } \\
\text { obstruction } 50 \% \text { dose } \\
\text { reduction in patients } \\
\text { with creatinine } \\
\text { clearance }<30 \mathrm{ml} / \\
\text { min Discontinue } \\
\text { maintenance laxatives } \\
\text { prior to initiation of } \\
\text { oral therapy; reinitiate } \\
\text { laxative therapy after } 3 \\
\text { days of poor response } \\
\text { for oral administration, } \\
\text { absorption/distribution } \\
\text { may be reduced when } \\
\text { taken with high fat } \\
\text { meals }\end{array}$ \\
\hline Naloxegol & $25 \mathrm{mg}$ orally once daily & Less than 2 hours & $\begin{array}{l}\text { Decrease dose to } \\
12.5 \mathrm{mg} \text { when used } \\
\text { concomitantly } \\
\text { with moderate } \\
\text { CYP3A4 inhibitors; } \\
\text { contraindicated } \\
\text { with strong CYP3A4 } \\
\text { inhibitors Decrease } \\
\text { dose to } 12.5 \mathrm{mg} \text { in } \\
\text { patients with creatinine } \\
\text { clearance }<60 \mathrm{ml} / \mathrm{min} \\
\text { Contraindicated with } \\
\text { known or suspected } \\
\text { gastrointestinal } \\
\text { obstruction }\end{array}$ \\
\hline Lubiprostone & $\begin{array}{l}24 \mathrm{mcg} \text { orally twice daily with food and } \\
\text { water }\end{array}$ & Within 24-48 hours & $\begin{array}{l}\text { Take with food to } \\
\text { reduce nausea }\end{array}$ \\
\hline Metoclopramide & $10 \mathrm{mg}$ orally/intravenously four times daily & $\begin{array}{c}\text { Oral: } 30 \text { - } 60 \text { minutes; Intravenous: } \\
\text { 1-3 minutes; Intramuscular: } 10 \text { to } 15 \\
\text { minutes }\end{array}$ & $\begin{array}{l}\text { Extrapyramidal effects } \\
\text { may occur at higher } \\
\text { doses and is more likely } \\
\text { in younger patients, } \\
\text { diphenhydramine may } \\
\text { temper }\end{array}$ \\
\hline Erythromycin & $\begin{array}{c}250 \text { to } 500 \mathrm{mg} \text { (base) orally } 3 \text { times daily } \\
\text { before meals }\end{array}$ & $\begin{array}{l}\text { Limit duration of therapy, tachyphylaxis } \\
\text { may occur after } 4 \text { weeks }\end{array}$ & $\begin{array}{l}\text { Consider in patients } \\
\text { refractory/intolerant to } \\
\text { other prokinetic agents } \\
\text { (e.g metoclopramide, } \\
\text { domperidone) }\end{array}$ \\
\hline
\end{tabular}

\section{*Avoid rectal administration in neutropenic patients}

Our strategy for prevention or early management of constipation begins with utilizing various agents notably overthe-counter medications. Stimulant laxatives include products containing Senna or bisacodyl. These laxatives increase intestinal motility and the secretion of water into the bowel.6,7
They generally produce bowel movements within hours, but may cause abdominal cramping. Stimulant laxatives should not be used in patients with suspected intestinal obstruction. Emollient laxatives or stool softeners, (e.g. docusates), act by lowering surface tension, allowing water to enter the bowel more readily 
$[6,7]$. They are generally well tolerated and may be particularly useful for patients with anal fissures or hemorrhoids that cause painful defecation. A common "mush and push" regimen to start with agents that are highly associated with constipation is the scheduled combination of Senna and docusate starting concomitantly with therapy and titrated to affect.

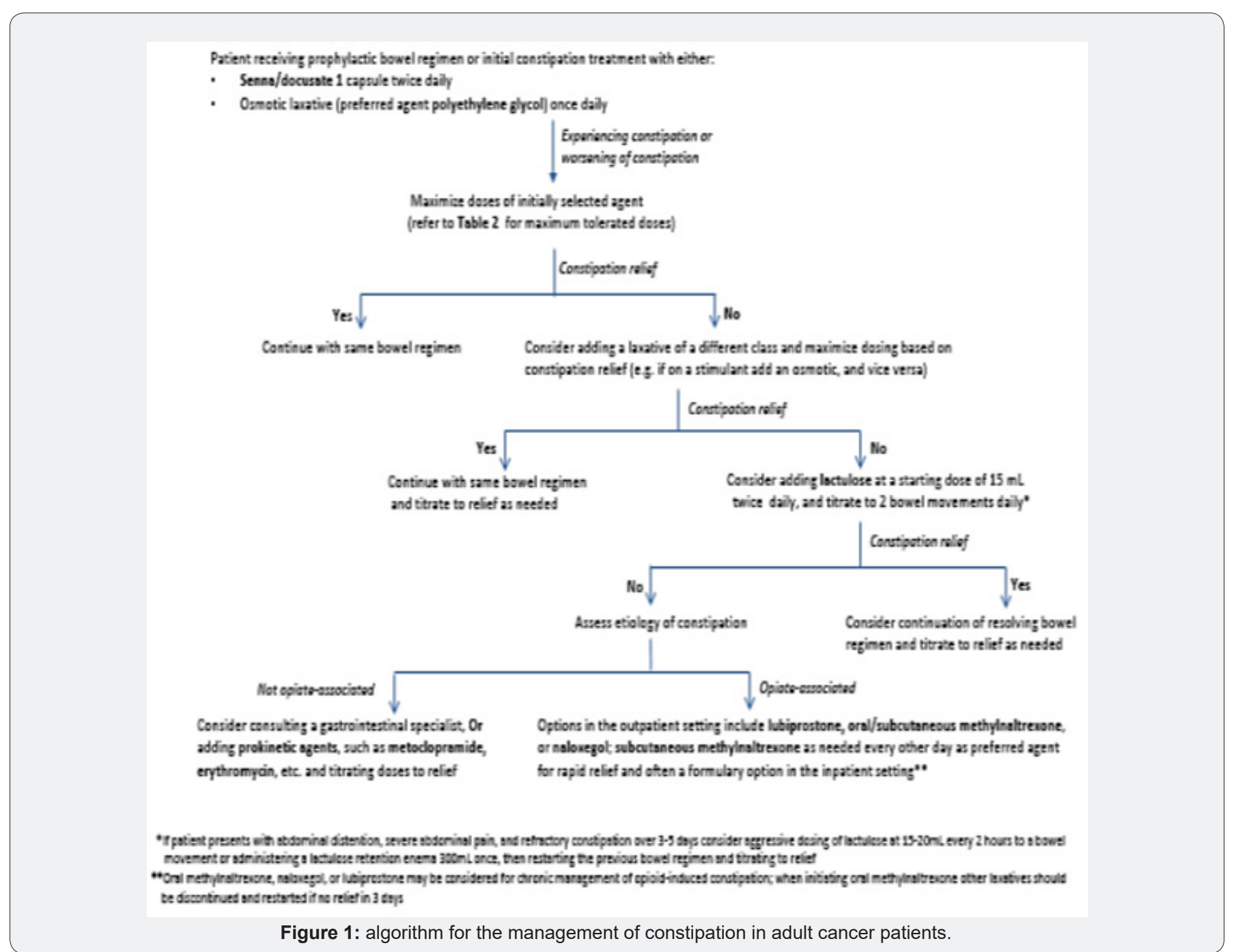

Saline/osmotic laxatives are hyperosmolar agents that cause secretion of water into the intestinal lumen by osmotic activity $[6,7]$. The most commonly used osmotic saline laxatives are oral magnesium hydroxide or oral magnesium citrate. These agents are considered relatively safe because they work within the colonic lumen without systemic effects. Saline laxatives have been associated with electrolyte imbalance within the colonic lumen and may precipitate hypokalemia, fluid and salt overload, and diarrhea. Hence, caution is warranted particularly in patients with congestive heart failure and chronic renal insufficiency. Osmotic laxatives such as sorbitol, lactulose, and polyethylene glycol (PEG) 3350 with or without electrolytes are often considered as alternatives to stimulants (Senna and docusate, or bisacodyl). Furthermore, they may also be used in conjunction with stimulant laxatives (Figure 1) for refractory constipation.

Several prokinetic agents have been studied for the treatment of constipation (erythromycin for example may commonly be applied to therapy) [8] Notably, metoclopramide may be effective for delayed gastric emptying when used prior to meals and at bedtime. Extrapyramidal symptoms are a common concern and occur more often at higher doses (1 to $2 \mathrm{mg} / \mathrm{kg}$ ), at which point diphenhydramine may be administered to reduce this risk [8]. Each of these agents accelerates colonic transit time and increase stool frequency in patients with constipation.

In patients experiencing severe or refractory constipation due to the chronic use of opioids, there are novel options to consider. Methylnaltrexone bromide is a peripherally acting $\mu$-opioid receptor antagonist that is administered via subcutaneous injection every other day as needed [9]. The average time to laxation after the first dose was 6.3 hours with no evidence of withdrawal symptoms or reversal of analgesia. Lubiprostone is a locally acting chloride channel activator that increases intestinal fluid secretion without altering serum sodium or potassium levels [9]. The increased fluid secretion in the intestines serves to improve intestinal motility, allowing easier passage of stool. 
Naloxegol is a derivative of the $\mu$-opioid receptor antagonist naloxone and has a pegylated chemical structure that prohibits crossing of the blood-brain barrier so that it maintains a solely peripheral mechanism [9]. It is recommended to discontinue other laxatives when starting naloxegol, however, other laxatives may be restarted if the patient does not produce a bowel movement within 72 hours after initiation. Linaclotide is a potent guanylate cyclase- $\mathrm{C}$ agonist that acts peripherally to increase the production of cyclic guanosine monophosphate in human colon cells, leading to eventual activation of the CFTR to increase chloride, bicarbonate, and water secretion into the colon [9]. When considering the prolonged use of any of these agents consulting gastrointestinal specialists may be prudent to help weigh the cost benefit as well as these compared with other options. While not all of these agents are indicated for constipation in cancer patients, they are valuable considerations in our supportive care arsenal [10].

Despite the availability of various classes of laxatives, constipation remains quite common among cancer patients. This may be attributed to failure to initiate laxatives in a timely manner i.e. before this condition arises in addition to the lack of guidelines to help select the most appropriate agents. Hence, the primary objective of this review is to provide clinicians with a practical or a real-world approach for managing constipation which is essential or pivotal for the care of patients with cancer [11].

\section{References}

1. Higgins PD, Johanson JF (2004) Epidemiology of constipation in North America: a systematic review. Am J Gastroenterology 99(4): 750-759.

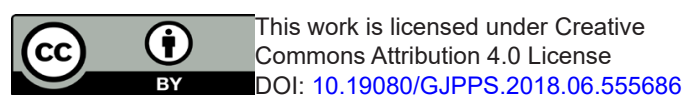

2. Bharucha AE, Pemberton JH, Locke GR (2013) American Gastroenterological Association technical review on constipation. Gastroenterology 144(1): 218-238.

3. Longstreth GF, Thompson WG, Chey WD, Houghton LA, Mearin F, Spiller RC (2006) Functional bowel disorders. Gastroenterology 130(5): 1480-1491.

4. Ternent CA, Bastawrous AL, Morin NA, Ellis CN, Hyman NH (2007) Standards Practice Task Force of the American Society of Colon and Rectal Surgeons. Practice parameters for the evaluation and management of constipation. Disorders of Colon and Rectum 50(12): 2013-2022.

5. Jamshed N, Lee Z, Olen K (2011) Diagnostic Approach to Chronic Constipation in Adults. Am Fam Physician 8(4): 299-306.

6. Hsieh C (2005) Treatment of Constipation in Older Adults. Am Fam Physician 72: 2277-84.

7. Avila JG (2004) Pharmacologic Treatment of Constipation in Cancer Patients. Cancer Control 11(3): 10-18.

8. Camilleri M, Parkman HP, Shafi MA, Thomas L Abell, MD, Lauren Gerson MD (2013) Clinical Guideline: Management of Gastroparesis. Am J Gastroenerol 108(1): 18-37.

9. Mc Fee Winans AR, Pawasauskas J, Sera L (2015) Opioid-Induced Constipation. Journal of Hematology Oncology Pharmacy 5(4): 111114.

10. Talley NJ, Jones M, Nuyts G, Dubois D (2003) Risk factors for chronic constipation based on a general practice sample. Am J Gastroenterology 98(5): 1107-1111.

11. McQuade RM, Stojanovska V, Abalo R, Bornstein JC, Nurgali K (2016) Chemotherapy-Induced Constipation and Diarrhea: Pathophysiology, Current and Emerging Treatments. Front Pharmacol 7: 414.

\section{Your next submission with Juniper Publishers will reach you the below assets}

- Quality Editorial service

- Swift Peer Review

- Reprints availability

- E-prints Service

- Manuscript Podcast for convenient understanding

- Global attainment for your research

- Manuscript accessibility in different formats

( Pdf, E-pub, Full Text, Audio)

- Unceasing customer service

Track the below URL for one-step submission

https://juniperpublishers.com/online-submission.php 